Louisiana State University

LSU Digital Commons

Faculty Publications

Department of Biological Sciences

$5-1-2006$

\title{
Conservation and restoration of the Pinus palustris ecosystem
}

Frank S. Gilliam

Marshall University

William J. Platt

Louisiana State University

Follow this and additional works at: https://digitalcommons.Isu.edu/biosci_pubs

\section{Recommended Citation}

Gilliam, F., \& Platt, W. (2006). Conservation and restoration of the Pinus palustris ecosystem. Applied Vegetation Science, 9 (1), 7-10. https://doi.org/10.1658/1402-2001(2006)9[7:CAROTP]2.0.C0;2

This Conference Proceeding is brought to you for free and open access by the Department of Biological Sciences at LSU Digital Commons. It has been accepted for inclusion in Faculty Publications by an authorized administrator of LSU Digital Commons. For more information, please contact ir@lsu.edu. 


\section{Marshall University}

Marshall Digital Scholar

Biological Sciences Faculty Research

Biological Sciences

$5-2006$

\section{Conservation and restoration of the Pinus palustris ecosystem}

Frank S. Gilliam

Marshall University, gilliam@marshall.edu

William J. Platt

Follow this and additional works at: http://mds.marshall.edu/bio_sciences_faculty

Part of the Forest Biology Commons, and the Other Ecology and Evolutionary Biology Commons

\section{Recommended Citation}

Gilliam FS and WJ Platt. 2006. Conservation and restoration of the longleaf pine ecosystem. Applied Vegetation Science 9:7-10.

This Article is brought to you for free and open access by the Biological Sciences at Marshall Digital Scholar. It has been accepted for inclusion in Biological Sciences Faculty Research by an authorized administrator of Marshall Digital Scholar. For more information, please contact zhangj@marshall.edu, martj@marshall.edu. 


\title{
Conservation and restoration of the Pinus palustris ecosystem
}

\author{
Gilliam, Frank S. ${ }^{*}$ \& Platt, William J. ${ }^{2}$ \\ ${ }^{1}$ Department of Biological Sciences, Marshall University, Huntington, WV 25755-2510, United Kingdom; \\ ${ }^{2}$ Department of Biological Sciences, Louisiana State University, Baton Rouge, LA 70803, USA; \\ *Corresponding author: Fax +1 3046963243; E-mail gilliam@marshall.edu
}

\begin{abstract}
The well-documented decline of the Pinus palustris ecosystem has resulted from several anthropogenic influences, such as forest clearing (e.g. pine plantation forestry, agriculture) and urban development, both of which are closely related to increases in human populations. Other impacts have arisen from alterations in disturbance regimes responsible for maintaining the structure and function of these ecosystems. Restoration and management of degraded pine savanna ecosystems is critical. Identification of ecological processes that determine the structure and function of the intact system are important because successful restoration efforts should be based on sound scientific understanding. In this paper, we introduce this special issue on the ecology, conservation, and restoration of the Pinus palustris ecosystem. Some global climate change scenarios have suggested that future changes may occur that alter frequency and severity of disturbances such as fires and hurricanes. Such changes may have large effects on pine stands, and ultimately entire Pinus palustris savanna ecosystems, thus presenting further challenges to their sustainable management.
\end{abstract}

Keywords: Conservation ecology; Fire ecology; Longleaf pine; Old-growth forest; Restoration ecology; U.S. Coastal Plain.

\section{Introduction}

Fire-maintained pine savannas were historically predominant in uplands throughout the coastal plain of the southeastern United States (Platt 1999). These savannas, dominated by Pinus palustris (longleaf pine) in the overstorey and a number of warm season grasses in the diverse ground cover, have been under chronic anthropogenic pressure over $>250$ years of European settlement (Sharitz et al. 1992; Frost 1993, 1998; Ware et al. 1993).

The current distribution of pine savannas dominated by $P$. palustris is $<3 \%$ of its original extent of $>25$ million ha. Much of this loss resulted from forest clearing, as well as conversion to agriculture and pine plantation forestry. The classic monograph by Wahlenberg (1946) cites late 19th century logging as a major cause for rapid reductions in stands of $P$. palustris in the southeastern U.S. by 1935. More recently, the human population of the southeastern U.S. has increased exponentially (Fig. 1). During this same period, the area of pine plantations here has increased linearly, while the land area containing $P$. palustris has decreased exponentially (Fig. 1). In addition, most remaining sites have experienced chronic exclusion or suppression of fire (Platt 1999). The 18th Tall Timbers Fire Ecology Conference, entitled 'The longleaf pine ecosystem: Ecology, restoration and management', focused on the decline of $P$. palustris (Hermann 1993). Despite these publications, declines continue relatively unabated.

As natural, intact areas of Pinus palustris vegetation are now rare, ecologically sound restoration and management of degraded pine savannas have become crucial for sustaining this high biodiversity system and its many unique species. Identification of ecological processes that determine structure and function of intact pine savannas is important because restoration efforts should be based on a solid scientific understanding of the ecology of such ecosystems (e.g. Doren et al. 1993; Moore et al. 1999; Provencher et al. 2001; Beckage \& Platt 2003; Slocum et al. 2003; Beckage et al. 2006). The two general objectives of this special feature are focused toward generating scientifically-based conservation of pine savannas. First, what quantitative data from old-growth longleaf pine stands and ground cover should be most useful in conservation? Southeastern pine savanna ecosystems contain two contrasting components of vegetation. The overstorey is typically comprised of one to a few tree species, but the ground cover is a highly diverse assemblage of grasses, forbs, shrubs, and tree seedlings (Fig. 2). These components are differentially influenced by the two most important disturbance regimes: hurricanes (episodic, largely affecting the overstorey) and fire (frequent, profoundly affecting the ground cover). Thus, each structural component of pine savannas should be useful in formulating a scientific basis for restoration and management.

Second, how can global change-mediated alterations in disturbance regimes be incorporated in strategies of conservation management? Global climate change 


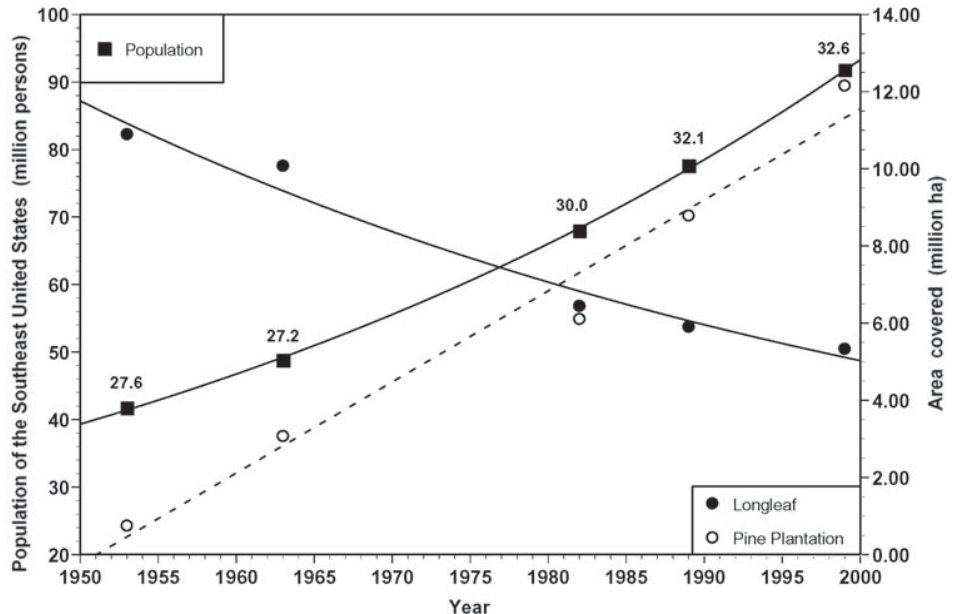

Fig. 1. Changes in population of the southeastern United States, area of Pinus palustris stands, and area of pine plantations over the past 50 years. Curves and line are shown to provide the best fit (highest $r$ ) to the trends. Relationships for population and area of $P$. palustris are exponential $\left(r^{2}=\right.$ 0.9995 and 0.97 , respectively), whereas the increase for area of pine plantations is linear $\left(r^{2}=0.97\right)$. Numbers above the symbols for population are the percentage of the population of the United States that is in the southeast. Data taken from Ware et al. (1993) and Wear \& Greis (2002). scenarios indicate changes in both fire and hurricane regimes. Given the complex factors that influence global weather phenomena such as tropical storms, it is not surprising that much debate remains regarding the potential impact of global warming on tropical storm fre-

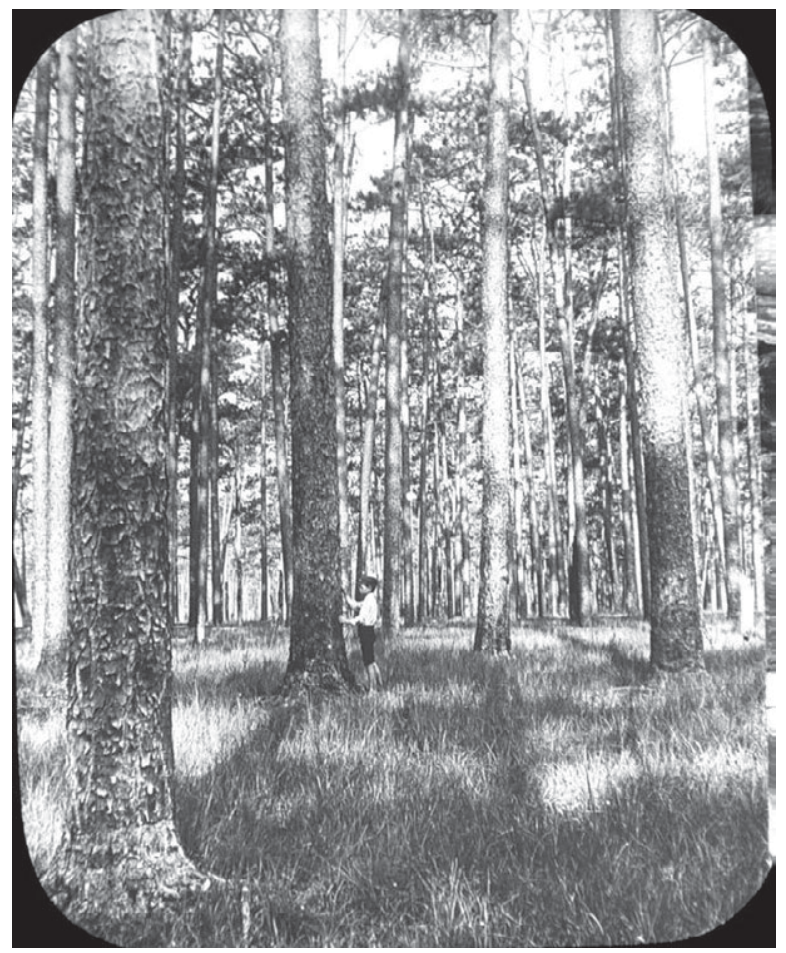

Fig. 2. Photograph of old-growth Pinus palustris stand, ca. 1902, Baldwin County, Alabama. American Environmental Photographs Collection, Image Number AEP-ALS1, Department of Special Collections, University of Chicago Library. quency and intensity. Empirical data, however, suggest the possibility of increases in frequency of tropical storms, even in the near future. We have analysed data from the National Oceanographic and Atmospheric Administration (http://www .aoml.noaa.gov/hrd/hurdat/ DataByYearandStorm.htm) based on annual occurrence of tropical storms dating back to 1851. Frequency of tropical storms has increased significantly with time since 1851 ( $r=0.39, P<0.0001)$ (Fig. 3a). Frequency was significantly, linearly correlated $(r=0.44, P<$ $0.0001)$ with temperature over a similar time period (1881-2005) (Fig. 3b). Consistent with the conditions under which tropical storms develop (i.e., the buildup of heat in surface tropical ocean water), this relationship is best fit when the number of storms of a given year is compared with the mean annual temperature deviation for the previous year.

The papers of this special issue are grouped according to their area of emphasis into two broad subjects regarding the ecology and conservation of longleaf pine ecosystems. The first group comprises papers that address patterns and mechanisms of pine savanna biodiversity. Considering that most of the biodiversity of any forested ecosystem occurs in the lower vegetation strata, it is not surprising that most of the focus is on the diversity of the ground cover. The second group comprises papers that focus more specifically on conservation issues regarding longleaf pine savanna restoration and that develop models to further our understanding of how management and natural disturbances are related to conservation.

\section{Patterns and mechanisms of pine savanna diversity}

Focusing on dynamics of carnivorous plants (Sarracenia spp., pitcher plants), Brewer (2006) used field 

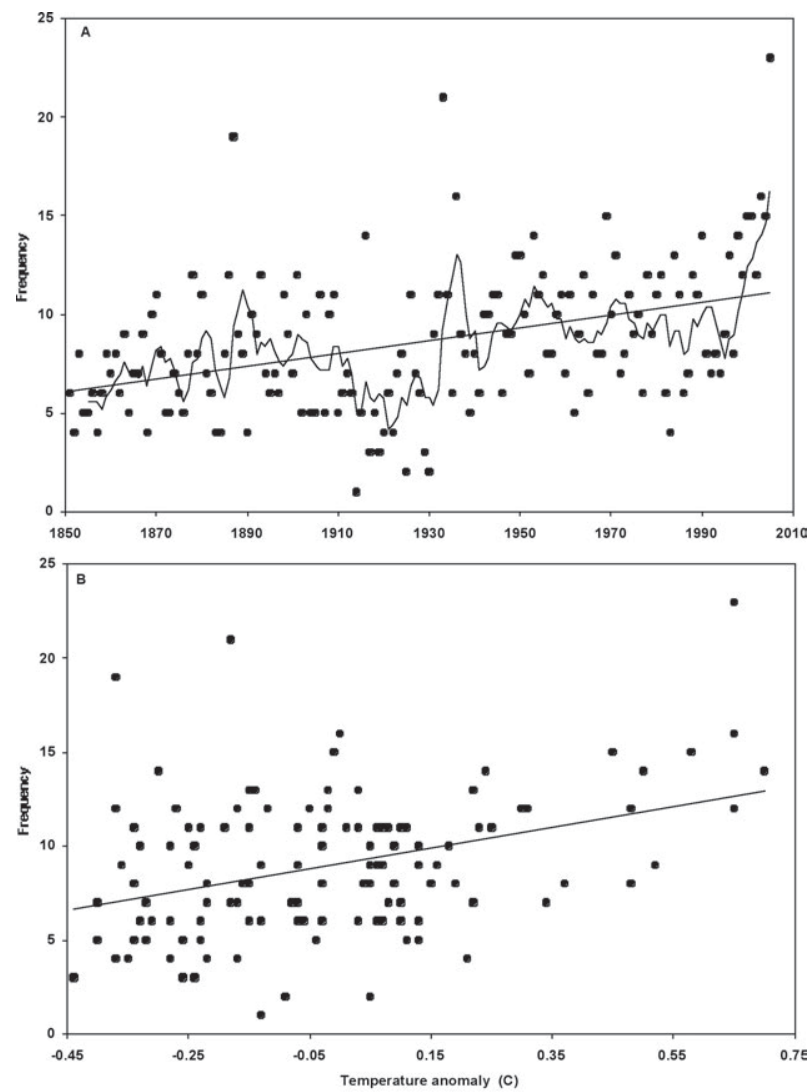

Fig. 3. Tropical storm activity in the northern Atlantic Ocean. A. Annual frequency from 1851-2005. Each point represents total of hurricanes and tropical storms for a given year as recorded by the National Oceanic and Atmospheric Administration. Trend line represents the 5-year moving average of storms, whereas the line represents a linear correlation of frequency vs. year; $r=0.41, P<0.0001$. B. Annual tropical storm frequency from 1881-2005 vs. mean annual temperature deviation from long-term average as recorded by the National Oceanic and Atmospheric Administration. Each point represents the sum of hurricanes plus tropical storms for a given year vs. mean annual temperature deviation for the previous year. Line shown represents linear correlation, $r=$ $0.44, P<0.0001$.

experiments to generalize that both fire and niche complementarity (particularly nutrient niches) are responsible for maintaining high species diversity in pine savannas. Dealing with flatwoods pine savannas of southeastern Louisiana, Keddy et al. (2006) concluded that most herbaceous species are weak competitors for light and hypothesized that many such species could be considered fugitive or peripheral species. In contrast to the other studies that focused on herb species, Drewa et al. (2006) examined the response of shrubs to varying fire regimes in pine savannas of northern Florida and eastern Louisiana, concluding that re-introduction of fires (e.g., associated with restoration efforts) during the growing season should be effective to either maintain, or even decrease, stem density of root crown-bearing shrubs, depending of species and fuel characteristics. Platt et al. (2006) removed patches of longleaf pine stems using ecologically-sensitive restoration logging to examine impacts on ground cover species. They concluded that restoration involving pine removal should benefit ground cover, particularly in frequently burned sites.

\section{Conservation and models of pine savannas}

Hamrick et al. (2006) emphasized the differences in tree versus herbaceous species in their respective mechanisms to maintain genetic diversity within species. They concluded that strategies for conservation of genetic diversity of herb species will be highly species-specific. Sorrie \& Weakley (2006) document a high level of endemism (1630 taxa) throughout the Coastal Plain of the southeastern U.S. They suggest that a combination of larger core reserves and small satellite reserves be used to maintain dispersed distribution of endemics. Kirkman \& Mitchell (2006) use a landscape perspective to develop a management model for the conservation of longleaf pine ecosystems. They further suggest that definitions of old-growth systems include undisturbed ground cover and the degree of fire-mediated connectivity of herb communities. Beckage et al. (2006) create a predictive model that combines Lotka-Volterra competition with predicted, global change-mediated changes in disturbance regimes (i.e. fire and hurricanes). Based on assumptions of future decreases in both disturbance types, they predict a shift from open savannas to close-canopied forests. Gilliam \& Platt (2006) compared ground cover composition and overstorey stand structure between the Wade Tract (old-growth longleaf stand experiencing frequent hurricanes and annual burning) versus the Boyd Tract (old-growth longleaf stand experiencing infrequent hurricanes and long-term fire exclusion) to develop a conceptual model that relates these disturbances to the demography and the physiognomic structure of $P$. palustris stands.

\section{Conclusions}

The papers presented in this special issue share a collective message. The underlying theme is that (1) restoration of degraded pine savannas should be carried out with the goal of providing ecological and evolutionary conditions resembling those prior to human alteration with a better understanding of what those condi- 
tions were, and (2) remnant old-growth overstorey and ground cover should be managed to prevent further degradation or, where appropriate, managed to restore old-growth stands that have experienced chronic fire exclusion. The diverse perspectives and topics regarding the ecology and conservation of pine savanna ecosystems, such as those in this issue, emphasize the need for restoration and management in a time of rapid environmental change and loss of habitat.

In contrast to the decline, pine savannas have long experienced a wealth of ecological attention in the form of scholarly publications (e.g. Wahlenberg 1946; Hermann 1993) and popular non-fiction (e.g. Ray 1999; Earley 2004). We anticipate that this special issue will add to this body of literature by combining the basic scientific perspectives of plant and forest ecologists with the more applied approaches taken by forest managers and restoration ecologists.

\section{References}

Beckage, B. \& Platt, W.J. 2003. Predicting severe wildfire years in the Florida Everglades. Frontiers Ecology Environ. 1:235-239.

Beckage, B., Platt, W.J., Slocum, M.G. \& Panko, R. 2003. Influence of the El Niño-Southern Oscillation on fire regimes in the Florida Everglades. Ecology 84: 3124-3130.

Beckage, B., Gross, L. \& Platt, W.J. 2006. Responses of pine savannas to climate change and large-scale disturbances. Appl. Veg. Sci. 9: 75-82.

Brewer, S. 2006. Resource competition and fire-regulated nutrient demand in plants of Pinus palustris savannas. Appl. Veg. Sci. 9: 11-16.

Doren, R.F., Platt, W.J. \& Whiteaker, L.D. 1993. Density and size structure of slash pine stands in the everglades region of south Florida. For. Ecol. Manage. 59: 295-311.

Drewa, P.B., Thaxton, J.M. \& Platt, W.J. 2006. Responses of root-crown shrubs to differences in Pinus palustris savanna fire regimes: exploring old-growth questions in second-growth systems. Appl. Veg. Sci. 9: 27-36.

Earley, L.S. 2004. Looking for longleaf: the rise and fall of an American forest. The University of North Carolina Press, Chapel Hill, NC, US.

Frost, C.C. 1993. Four centuries of changing landscape patterns in the longleaf pine ecosystem. In: Hermann, S.M. (ed.) The longleaf pine ecosystem: ecology, restoration and management, pp. 17-44. Proceedings, 18th Tall Timbers Fire Ecology Conference, Tall Timbers Research, Inc., Tallahassee, FL, US.

Frost, C.C. 1998. Presettlement fire frequency regimes of the United States: a first approximation. In: Pruden, T.L. \& Brennan,L.A. (eds.) Fire in ecosystem management: Shifting paradigm from suppression to prescription, pp. 70-81. Proceedings 20th Tall Timbers Fire Ecology Conference, Tall Timbers Research, Inc., Tallahassee, FL, US.

Gilliam, F.S.; Platt, W.J. \& Peet, R.K. 2006. Natural distur- bances and the physiognomy of pine savannas: a phenomenological model. Appl. Veg. Sci. 9: 83-96.

Hamrick, J., Godt, M.J.W . \& Gonzales, E. 2006. Conservation of genetic diversity in old-growth forest communities. Appl. Veg. Sci. 9: 51-57.

Hermann, S.M. 1993. The longleaf pine ecosystem: ecology, restoration and management. Proceedings of the 18th Tall Timbers Fire Ecology Conference. Tall Timbers Research, Inc., Tallahassee, FL, US.

Keddy, P.A., Smith, L., Campbell, D.R., Clark, M. \& Montz, G. 2006. Patterns of herbaceous plant diversity in a Louisiana pine savanna. Appl. Veg. Sci. 9: 17-26.

Kirkman, K. \& Mitchell, R. 2006. Conservation management of Pinus palustris ecosystems from a landscape perspective. Appl. Veg. Sci. 9: 67-74.

Moore, M.M., Covington, W.W.\& Fulé, P.Z. 1999. Reference conditions and ecological restoration: a southwestern ponderosa pine perspective. Ecol. Appl. 9: 1266-1277.

Platt, W.J., Carr, S.M., Reilly, M. \& Fahr, J. 2006. Pine savanna overstory influences ground cover biodiversity. Appl. Veg. Sci. 9: 37-50.

Provencher, L., Herring, B.J., Gordon, D.R., Rodgers, H.L., Galley, K.E.M., Tanner, G.W., Hardesty, J.L., \& Brennan, L.A. 2001. Effects of hardwood reduction techniques on longleaf pine sandhill vegetation in northwest Florida. Restor. Ecol. 9:13-37.

Ray, J. 1999. Ecology of a cracker childhood. Milkweed Editions, Minneapolis, MN, US.

Sharitz, R.R., Boring, L.R., Van Lear, D.H. \& Pinder, III, J.E. 1992. Integrating ecological concepts with natural resource management of southern forests. Ecol. Appl. 2: 226-237.

Slocum, M.G., Platt, W.J., \& Cooley, H.C. 2003. Effects of differences in prescribed fire regimes on patchiness and intensity of fires in subtropical savannas of Everglades National Park, Florida. Restor. Ecol. 11:91-102.

Sorrie, B. \& Weakley, A. 2006. Developing a blueprint for conservation of the endangered Pinus palustris ecosystem based on centres of Coastal Plain plant endemism. Appl. Veg. Sci. 9: 59-66.

Wahlenberg, W.G. 1946. Longleaf pine: its use, ecology, regeneration, protection, growth and management. Charles Lathrop Pack Forestry Foundation, Washington, DC, US.

Ware, S., Frost, C. \& Doerr, P.D. 1993. Southern mixed hardwood forest: the former longleaf pine forest. Chapter 10. In: Martin, W.H.., Boyce, S.G. \& Echternacht, A.C., (eds.) Biodiversity of the southeastern United States. Lowland terrestrial communities, pp. 447-493. John Wiley \& Sons, New York, NY, US.

Wear, D.N. \& Greis, J.G. (eds.) 2002. Southern forest resource assessment. Gen. Tech. Rep. SRS-53. Department of Agriculture, Forest Service, Southern Research Station, Asheville, NC, US.

Received 28 July 2004; Accepted 11 November 2005. Co-ordinating Editor: R.K. Peet. 